NBER WORKING PAPER SERIES

\title{
RETHINKING STABILIZATION POLICY: EVOLUTION OR REVOLUTION?
}

Olivier J. Blanchard

Lawrence H. Summers

Working Paper 24179

http://www.nber.org/papers/w24179

\author{
NATIONAL BUREAU OF ECONOMIC RESEARCH \\ 1050 Massachusetts Avenue \\ Cambridge, MA 02138 \\ December 2017
}

Thanks to Vivek Arora, Ben Bernanke, Giovanni dell'Ariccia, Bill Cline, Stanley Fischer, Morris Goldstein, Greg Ip, Colombe Ladreit, Thomas Pellet, Lukasz Rachel, Martin Sandbu, Andrei Shleifer, Robert Solow, Anna Stansbury, Nicolas Veron, and David Vines for comments. Thanks to Andrew Sacher for research assistance. Prepared for the "Rethinking macro policy" conference at the Peterson Institute for International Economics, October 2017. The views expressed herein are those of the authors and do not necessarily reflect the views of the National Bureau of Economic Research. The papers presented at the conference and podcasts of the presentations are available at https://piie.com/events/rethinking-macroeconomic-policy

NBER working papers are circulated for discussion and comment purposes. They have not been peer-reviewed or been subject to the review by the NBER Board of Directors that accompanies official NBER publications.

(C) 2017 by Olivier J. Blanchard and Lawrence H. Summers. All rights reserved. Short sections of text, not to exceed two paragraphs, may be quoted without explicit permission provided that full credit, including $\odot$ notice, is given to the source. 
Rethinking Stabilization Policy: Evolution or Revolution?

Olivier J. Blanchard and Lawrence H. Summers

NBER Working Paper No. 24179

December 2017

JEL No. E02,E20,E31,E32,E42,E5,E62

\section{ABSTRACT}

The obvious lesson from the Great Financial Crisis is that the financial system matters and financial crises will probably happen again. The second, more general, lesson is that the economy is often not self-stabilizing. These two lessons, together with an environment where neutral interest rates are likely to remain low, have clear implications for the design of stabilization policies.

At a minimum, they suggest that policies may need to become more aggressive, both ex-ante and ex-post, with a rebalancing of the roles of monetary, fiscal and financial policies. In particular, while low neutral rates decrease the scope for using monetary policy, they increase the scope for using fiscal policy. Think of such rebalancing as evolution. If however, neutral rates become even lower, or financial regulation turns out to be insufficient to prevent crises, more dramatic measures, including larger fiscal deficits, revised monetary policy targets, or sharper restrictions on the financial system, may be needed. Think of this as revolution. Time will tell.

Olivier J. Blanchard

Peterson Institute for International Economics

1750 Massachusetts Avenue, NW

Washington, DC 20036

and NBER

oblanchard@piie.com

Lawrence H. Summers

Harvard Kennedy School of Government

79 JFK Street

Cambridge, MA 02138

and NBER

lhs@harvard.edu 
Nearly ten years after the onset of the Great Financial Crisis, both researchers and policy makers are still assessing the policy implications of the crisis and its aftermath. Previous major crises, from the Great Depression to the stagflation of the 1970s, profoundly changed both macroeconomics and macroeconomic policy. The question is whether this crisis should and will have similar effects.

We believe it should, although we are less sure it will. Rather obviously, the crisis has forced macroeconomists to (re)discover the role and the complexity of the financial sector, and the importance of financial developments, including financial crises, in affecting economic activity. But the lessons should go largely beyond this, and force us to question a number of cherished beliefs. Among other things, the events of the last ten years have put into question the presumption that economies are self stabilizing, and have raised again the issue of whether temporary shocks can have permanent effects.

These call for a reappraisal of macroeconomic thinking and macroeconomic policy. As the paper was written as a curtain raiser for a conference that looks in more detail at the implications for specific policies, we make no attempt at being encyclopedic and feel free to pick and choose the issues which we see as most salient. ${ }^{1}$

In Section 1, we review the response to two previous major crises, the Great Depression of the 1930s, and the stagflation of the 1970s. The first led to the Keynesian revolution, a worry about destabilizing processes, a focus on aggregate demand and the crucial role of stabilization policies, and to tighter constraints on the financial system. The second led instead to the partial rejection of the Keynesian model, a more benign view of economic

\footnotetext{
${ }^{1}$ We also limit our focus to stabilization issues, referring in particular the reader to the presentations at the conference on open economy issues (Gopinath 2017), and on the relation between macroeconomic policy and inequality (Furman 2017).
} 
fluctuations and the self-stabilizing properties of the economy, a focus on simple policy rules, and a more relaxed attitude vis a vis the financial system. The question is then what this crisis should and will do.

In Section 2, we focus on what we see as the main three lessons from the last ten years. First, and not surprisingly, the crucial role of the financial sector and the costs of financial crises; second, the complex nature of fluctuations, from the role of non-linearities in leading to potentially exploding or imploding paths, to the limits of policy, to the persistent effects of shocks; third, the fact that we are and may be for the foreseeable future in an environment of low nominal and real interest rates, an environment which interacts with the first two factors, and forces a rethinking not only of monetary, but also of fiscal and financial policies.

We then focus on the joint implications of these changes for monetary, fiscal, and financial policies.

In Section 3, we focus on the implications for monetary policy. In an environment of low neutral rates and higher perceived risks, we see the main challenge facing monetary policy as being how to deal with the liquidity trap, both ex-ante and ex-post. Should the inflation target be increased? Should central banks adopt a price level or a nominal GDP target? Can the scope for negative nominal interest rates be widened? We believe the issue must be tackled now even in countries where the constraint is not currently binding.

We also take up two other issues. First, whether and how monetary policy should concern itself with financial stability; we conclude that monetary policy can be of little help, and so financial stability must inevitably depend on financial policies, as imperfect as they might be. Second, how central banks should deal with the large balance sheets they have accumulated as a result of the crisis; we conclude that there is no strong reason for large central bank to keep those large balance sheets. To the extent that there are 
reasons to affect spreads, this is better handled through debt management and fiscal policy.

In Section 4, we focus on the implications for fiscal policy. In an environment of limits to monetary policy, and neutral interest rates below growth rates, we argue that fiscal policy will inevitably play a much more active role in stabilization. Automatic stabilizers can be made more potent and effective with policy effort. And, in an environment in which the interest rate is likely to remain below the growth rate for some time to come, the usual discussion of debt sustainability must be reexamined. At a minimum, debt consolidation can take place more slowly and there are additional arguments for debt-financed increased public investment.

In Section 5, we focus on financial policies, from financial regulation to macroprudential and microprudential policies. While many measures have already been adopted, how best to address financial risks, both ex-ante and ex-post, remains uncertain. We take up two issues. First, whether simple tools, such as capital ratios and stress tests, are sufficient to assure financial stability. The evidence makes up skeptical that they will. Second, we address the mix between financial regulation and macro prudential policy. We conclude that having higher and constant capital ratios rather than lower and varying ones is likely to be more conducive to the maintenance of financial stability.

We state our conclusions in Section 6. Ten years ago, few would have predicted the events which were to unfold, from runs on the largest world financial institutions, to interest rates at liquidity trap levels for close to a decade, to inflation still below target today, to output gaps being still large and negative in many advanced economies. We observe a temptation to go back to the pre-crisis ways, a return to inflation targeting and to a Taylor-like rule, no use of fiscal policy for stabilization purposes, and pushback on financial reg- 
ulation and macroprudential measures. This temptation should be resisted. In what we now understand to be a world where financial instability, situations where lower bounds on interest rates, and protracted effects of cyclical downturns are ever present threats, strong stabilization policies are key. At a minimum, monetary policy must reestablish its margin of maneuver. Fiscal policy must be reintroduced as a major stabilization tool. And financial policies must continue to be adjusted and reinforced. Call this evolution. If however neutral rates remain extremely low, perhaps even negative, or financial regulation falls short, more dramatic changes may be needed, from reliance on fiscal deficits, to active policy efforts to promote private spending, to higher inflation to achieve lower real rates, and much tighter constraints on the financial sector. Call this revolution. Time will tell.

\section{Crises and macro policy changes of the past}

In the wake of the Great Depression, macroeconomists-at least in the English speaking world-converged on a common set of ideas that came out of Keynes' General Theory. Rather than being seen as inevitable, natural and mostly unproblematic like seasonal fluctuations, business cycles and recessions in particular came to be seen as highly problematic manifestations of shortfalls in aggregate demand. Maintaining adequate demand through the tools of fiscal and monetary policy became the primary concern of macroeconomic policy. And, in the light of the financial crisis at the origin of the depression, governments took a much heavier hand in managing financial systems, regulating rates on bank liabilities, regulating the composition of bank assets, and, in some cases, limiting competition between financial intermediaries.

The very strong performance of the American and British economies during World War II was seen as a demonstration of the power of fiscal pol- 
icy. The subsequent strong performance of advanced economies led to great confidence in stabilization policy. One of us remembers being told as a child in the 1960s of how the U.S. Department of Commerce publication Business Cycle Digest had been renamed Business Conditions Digest so as to preserve the initials BCD but to reflect the fact that business cycles were no longer inevitable. Confidence in policy was based on conviction that deep understanding, reflected in large econometric models, had been achieved. There was, to be sure, a concern that increased economic activity would lead to increased inflation as reflected in the Phillips curve. But the idea was that prudent policymakers would choose an optimal point on the curve which would balance the benefits of higher output and less unemployment against the costs of higher inflation.

A combination of intellectual developments and real world events led to a dramatic reconceptualization of macroeconomics between the late 1960s and the early 1980s. Phelps(1968) and Friedman (1968) pointed out that, on theoretical grounds, one would not expect to see a stable tradeoff between inflation and unemployment as postulated by the simple Phillips curve. At the same time by the late 1970s, and in apparent contrast to the Keynesian view, stagflation emerged as a major problem throughout advanced economies as inflation and unemployment both increased in unison.

The result was again a dramatic change in macroeconomic thinking. By the mid-1980s the mainstream view was that there was no long-run tradeoff between inflation and unemployment. Fluctuations in output associated with changes in nominal demand were in the freshwater view an illusion, or in the saltwater view the temporary consequence of wage and price stickiness. Demand management policy could aspire to containing inflation and reducing the volatility of economic fluctuations but not to raising the average level of output over time. Reducing discretion in monetary policy 
through a combination of political insulation of central banks, the adoption of explicit targets and policy rules would contribute to improved economic performance with less inflation, no loss of output over time, and damped economic fluctuations. In parallel, financial regulation was relaxed, restrictions on commercial banks were gradually lifted. ${ }^{2}$

As a consequence of this change in thinking, all major central banks were granted substantial independence and set inflation targets as the principle guidepost for policy. It came to be accepted that one major stabilization policy tool was enough, and interest in fiscal policy diminished greatly. Events like the 1993 Deficit Reduction Program in the United States where deficit reduction led to lower interest rates at all maturities and an acceleration of growth encouraged the view that fiscal policy decisions should be made on long run grounds with little attention to issues of demand management.

The period from roughly the mid-1980s to the mid-2000s saw a steady decrease in the variance of inflation, unemployment, and output. Christened the "Great Moderation", it was widely seen as proof of success of the new approach to policy, in particular to monetary policy. To be sure, there were dramatic developments in financial markets over this period, notably the 1987 stock market crash, the bursting of the Japanese bubble in the early 1990s, the emerging markets' dramas in Latin America and Asia during the 1990s, and the bursting of the tech bubble in 2000. But these events were seen as a series of epiphenomena that could be dealt with on an ad-hoc basis and that did not, with the exception of the bursting of the Japanese bubble,

\footnotetext{
${ }^{2}$ This paragraph does not do justice to the factors behind the change in policy. Many forces were at work: The failure of the Keynesian approach was more apparent than real, due more to a failure to anticipate supply shocks, a failure which could be and was repaired ex post. This apparent failure was used however to promote an alternative approach to macroeconomics, more tightly based on micro foundations, more confidence in market outcomes, and less confidence in activist policy. While the academic view of macro tended to treat the financial system as an innocent veil, technological developments in computing power and intellectual developments such as option pricing formulas led to major changes in the structure of financial intermediation.
} 


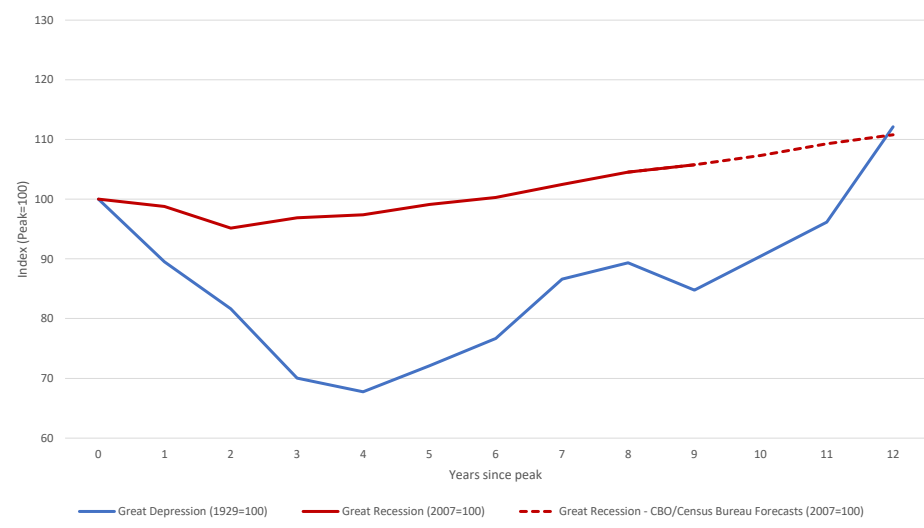

Figure 1: US real GDP per 18-64 year old. Great Recession versus Great Depression. $\quad$ Source: NIPA

lead to major changes in advanced economies' macro performance. Even the Japanese "lost decade" was interpreted as the result of a succession of policy failures rather than a challenge to the prevailing paradigm.

Indeed confidence that the business cycle had been tamed and that central banks had learned that they needed to respond rapidly to financial crises combined to enable then Governor of the Fed Ben Bernanke (2002) to apologize on behalf of the Fed for the Great Depression and make clear that such an event could not happen again given the understanding that had been achieved. While Bernanke's own aggressive actions in 2008 made his earlier statement prophetic as a replay of the Great Depression was indeed avoided, it is probably fair to assume that Bernanke's listeners in 2003 did not expect anything like the Great Financial Crisis to materialize. Yet, just as mounting confidence in the existing paradigm and policy approach was followed by disaster in the 1970s, the same thing happened again with the Great Financial Crisis. As Figure 1 illustrates, output per person of working age in the 
United States likely will have increased no more over the 12 years since 2007 than it did during the 12 years after 1929. ${ }^{3}$ The outcome is even worse in other parts of the advanced world.

Be it in monetary, fiscal, or financial policies, many measures were taken in the heat of the crisis. Ten years after the start of the crisis however, it is not clear however to what extent these extraordinary measures will be seen as one-off ad-hoc crisis responses and to what extent they will lead to a rethinking of both macroeconomics and macroeconomic policy similar to what we saw in the 1930s or in the 1970s. If so, in what ways should policy evolve? This is what we explore in the rest of the paper.

\section{Three main lessons}

We focus on what we see as three main lessons from the last decade, namely the centrality of finance, the more complex and problematic nature of fluctuations, and the implications of very low neutral interest rates.

\subsection{The Centrality of Finance}

Hyman Minsky (1992) had warned for decades about the consequences of buildups in financial risk. The NBER (1991) and others had held conferences on financial crisis risk. Financial crises were endemic in emerging market countries. And, in advanced countries, the poor performance of Japan after the bursting of the bubble was there for all to see. Yet, prevailing macroeconomic paradigms largely ignored the possibility of financial developments as drivers of economic performance. Neither financial euphoria as a source of booms, nor financial crisis as a cause of busts, played a prominent role

\footnotetext{
${ }^{3}$ This reflects in part the very strong growth in 1940 and 1941, due to the mobilization for war.
} 
in the macroeconomic thinking of academics or policy makers. In macroeconomic models, the role of the financial system was often reduced to the determination of a yield curve and stock prices, based mostly on the expectation hypothesis with fixed term premia.

The crisis has obviously changed that. It has triggered a very large amount of research on the entrails and the behavior of the financial system. ${ }^{4}$ But many questions remain unanswered, and there is not as yet a canonical model of a financial crisis. Let us give two examples of issues crucial for policy that remain unresolved:

First, granting that asset price or credit bursts and their interaction with excessive leverage are crucial in understanding financial crises, what is the relative importance of different mechanisms? One mechanism is that financial intermediaries lose capital and respond by cutting back lending thereby choking off economic activity. This aspect dominates the accounts of the 2008 crisis by Paulson (2010), Bernanke (2015), and Geithner (2014). Another is, instead, that excessive indebtedness coupled with declining asset values lead consumers and businesses to retrench and cutback on consumption and investment, a mechanism emphasized by Koo (2011) and Mian and Sufi (2014).

Which channel dominates is a central issue for policy. If the second channel is the most important, measures that write off existing debts are crucial to the resolution of financial crisis. This is the position taken by those like Geanakoplos (2010) who believe that the failure to write off mortgage debt on a large scale was a grave error in the United States' handling of the financial crisis. If on the other hand, the key issue is impairment of intermediaries, then such debt writedowns may be highly counterproductive by

\footnotetext{
${ }^{4}$ Anybody who questions the ability of the economics profession to respond to events should look for example at the long list and the content of NBER working papers dealing with the financial system since 2008 .
} 
substantially reducing the regulatory capital of intermediaries and leading them to scale back lending. Indeed for an institution that is constrained in its lending by an 8 percent regulatory capital requirement, each dollar of imposed capital losses may reduce lending by up to $\$ 12$. It may be that both aspects are central, but at different stages of the crisis: Addressing the first may be essential early on to avoid the economy going into free fall, reducing debt overhangs may be crucial later in making rapid recovery possible. On which side to intervene and when are still very much open issues. ${ }^{56}$

Second, the age-old issue of the relative roles of solvency versus liquidity in precipitating a crisis is still not settled. Official sector accounts of the crisis in the United States suggest that the problems at the major institutions were primarily problems of liquidity rather than solvency-a judgment supported by the finding of the April 2009 stress tests that very little capital was required by the major financial institutions and by the observation that the vast majority of the TARP funds were paid back quite quickly. On the other hand, critics like Bulow and Klemperer (2013) have noted there were substantial reasons to doubt the solvency of some of the largest banks as early as the summer of 2008 and point out that the stress tests represented a kind of implicit liability guarantee for the banks which was like the government providing capital without charging for it. In that view, the success of TARP may have been accidental, the result of a gamble for resurrection that turned out right. While Diamond and Dybvig's (1983) celebrated paper on bank runs provides a framework for thinking about liquidity crises, the question of how to deal, in the midst of a generalized crisis, with institutions that are suddenly recognized to be in trouble, remains open.

\footnotetext{
${ }^{5}$ Another way of asking the question is to ask where debt should be relocated during and after the crisis, so as to allow the strongest recovery: With borrowers, with lenders, or with the state?

${ }^{6}$ Work by Ganong and Noel (2017) suggests that providing relief on debt service might be more cost-efficient than writing off debt altogether.
} 
In short, our understanding of the financial system has improved, but it remains limited. Add to this that the financial system is substantially more complex than it was in the past, that it is highly reactive to regulation, and that it is very good at regulatory arbitrage. The challenge facing financial policies is considerable. This has a straightforward implication: Financial crises will probably happen again.

\subsection{The nature of fluctuations}

Over the three decades before the crisis, macroeconomics had largely converged on a "shock and propagation mechanism" view of economic fluctuations in advanced economies. The economy was constantly hit by many shocks, some to components of demand and some to components of supply, most of them small, each of them with their own propagation mechanism. And one could think of these propagation mechanisms as largely linear, with the economy ultimately returning to potential after any given shock.

The technical machinery of modern macroeconomics was largely based on that view. In a world of shocks and linear mechanisms, one could think of vector autoregressions (VARs) as capturing the reduced form of these dynamics. Dynamic stochastic general equilibrium (DSGE) models could be constructed to fit and interpret the reduced form, and to give a deeper structural interpretation to the observed dynamics.

Not only did this view become the basic paradigm of much of macroeconomic research, but it shaped the design of macroeconomic policy. In a world of regular fluctuations, optimal policy takes the form of stable feedback rules. In the years before the crisis, the focus had been nearly exclusively on monetary policy, and much of the rather Talmudic discussion was about the precise form of the "interest rate rule", i.e. the best reaction function of the interest rate to inflation and to the output gap. Fiscal policy was 
ignored as a stabilization tool, although, inconsistently, policy makers were still happy to let existing automatic stabilizers function, no matter how accidental and unadapted they were. And macro prudential policies were simply not the subject of mainstream discussions.

The financial crisis does not fit this image of fluctuations, in a number of dimensions:

First, financial crises challenge how we should think of shocks. The notion of random shocks always raised nearly metaphysical issues: Presumably behind a shock to consumption or to wages is some deeper explanation, some underlying shock, which itself should be explained, etc. But, for a macroeconomist, it is reasonable to just take some unexplained movements as given, call them shocks, and not try to further explain them (Romer (2016) has made fun of such an approach, referring to such shocks as phlogistons.) One can indeed think of shocks to components of aggregate demand which affect output over time, with the effects building up and then disappearing over time. But this seems singularly unadapted to the description of financial crises. Such crises appear to build up slowly, either in the form of asset price bubbles or credit booms, until perceptions change, prices crash, and the financial system is impaired. The relevant image is much more of plate tectonics and earthquakes, than of regular random shocks.

Second, financial crises are characterized by essential non-linearities and positive feedback whereby shocks are strongly amplified rather than damped as they propagate. The quintessential example is bank runs, in which a small shock, or even no shock at all, leads creditors or depositors to run and makes their fears self fulfilling. This is where the discussion earlier of liquidity versus solvency is important: Liquidity is intrinsically associated with multiple equilibria or at least with large effects of small shocks.

Third, financial crises are followed by long periods of depressed output 


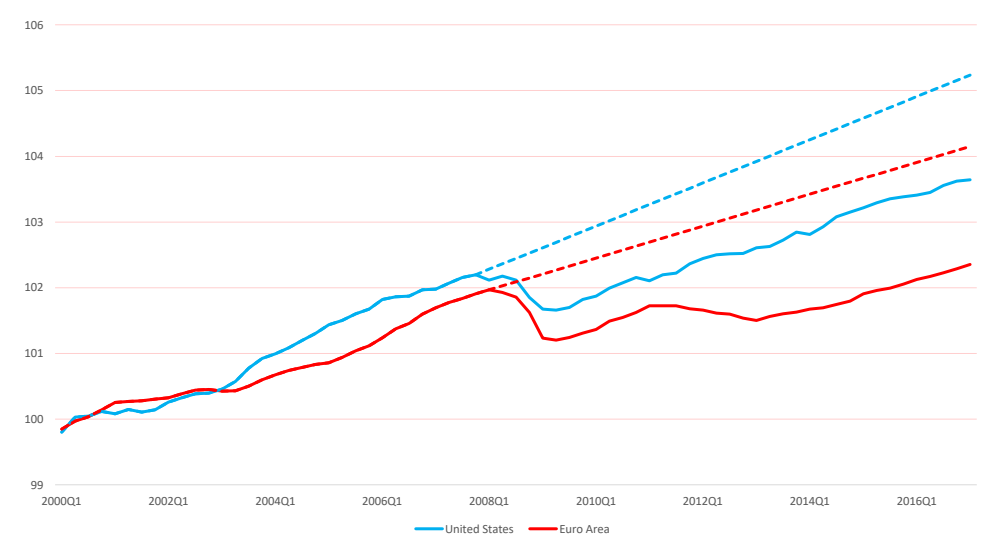

Figure 2: Advanced economies log real GDP and extrapolated trend (Index 2000-100). Source: Blanchard 2018

and the Great Financial crisis has been no exception. One of the most dramatic facts of the crisis is shown in Figure 2, which plots the evolution of log GDP in the United States and the European Union since 2000. In both cases, the crisis led to a step decrease in output relative to the pre-crisis trend (estimated over 2000-2008). In neither case does output appear to be returning to the old trend. This low growth has come largely as a surprise. For example Fed forecasts of GDP have been too optimistic in all of the last 6 years.

These evolutions have led to a revival of the hysteresis discussion, i.e. whether temporary shocks have persistent or even permanent effects on potential output. By itself, the evidence in Figure 2 is not dispositive:

It could be that these economies are still some distance from potential. Sharp limits on the scope of policies to sustain aggregate demand may have led to output remaining below potential even today. Indeed this is probably the case in much of the European Union. In the United States however, the low rate of unemployment suggests that output is now close to potential, 
and that what we are seeing is indeed lower potential output relative to the pre-crisis trend.

It could be the coincidence of two independent evolutions. On the one hand the sharp initial drop in output due to the crisis, and on the other, an underlying decrease in trend productivity growth, and thus lower trend growth of potential output, largely unrelated to the crisis. There is indeed some evidence that, at least in the United States, the decline in measured productivity growth started before the crisis, and thus may be due in part to other factors (for example, Fernald et al 2017). The evolutions shown in Figure 2 might, under this interpretation, reflect a return of output to a more slowly growing potential output trend.

It may be instead that financial crises are like permanent supply shocks, leading to a long lasting, perhaps even permanent, decrease in potential output relative to trend. They may lead to a less efficient financial intermediation system, which affects not only the demand side, but also the supply side. In the United States however, private debt levels have decreased, and the financial system no longer seems impaired. Or it may be that tighter regulation leads the financial system to finance lower risk but also, by implication, lower return, projects and thus lead to a lower if more stable potential output path.

Or, finally, it may be that recessions, especially deep recessions, affect potential output, that there is hysteresis (Phelps 1972, Blanchard and Summers 1986), either through higher unemployment, lower labor force participation, or lower productivity (Blanchard 2018). There is indeed some evidence that, in the United States, the high unemployment associated with the financial crisis has contributed to the decline in labor force participation.

Implications for policy depend on which of the mechanisms described above is most relevant. The first points to the need for ways of using demand policies more aggressively. The second and third point to the difficulties of 
assessing potential output. The fourth, on which we put some weight, has more dramatic implications, as it suggests that the effects of adverse shocks and thus the role of policy may be much larger than in a world in which potential output is unaffected by cyclical fluctuations.

Some of the issues we just discussed are specific to financial crises. But some apply to all fluctuations. The crisis has put into focus a number of firstorder non linearities, which are relevant more generally, even more so in the current low growth, low inflation, low interest rate, environment. The most obvious one is the lower bound on nominal interest rates, which, when it binds, leads the economy to have dramatically different responses to shocks and policies. Another, which has been binding in some southern European countries, is the zero lower bound on nominal wage changes. As for nominal interest rates, this zero lower bound is not absolute, and some nominal wages have declined, but it has strongly limited the usual process of wage and price adjustment to high unemployment. Yet another non linearity has come from the interaction between public debt and the banking system, a mechanism known as "doom loops", and which played a central role early in the euro crisis: Higher public debt leads to worries about public debt restructuring, decreasing the value of the bonds held by financial institutions, leading in turn to a decrease in their capital, worries about their health, and the expectation that the state may have to bail them out and be itself in trouble as a result.

In contrast to the standard pre-crisis view, these non linearities have the potential of amplifying initial shocks, potentially leading to implosive paths, leading again to strong policy challenges. 


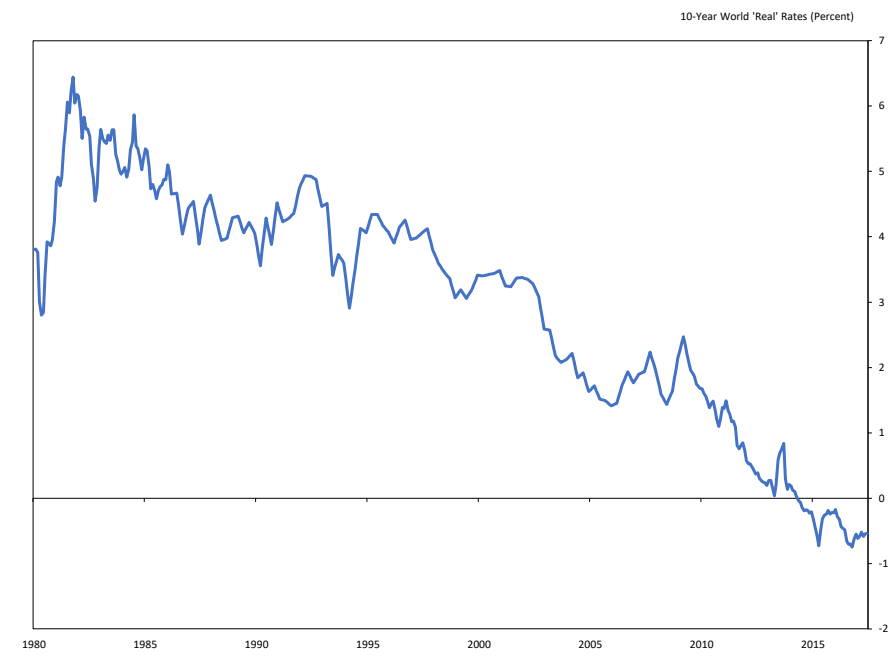

Figure 3: 10-year Real Rate on indexed bonds (G7 minus Italy). Source: Rachel and Smith 2015

\subsection{Low interest rates}

Low interest rates are a major feature of the current macroeconomic environment. Figure 3 shows the evolution of the 10-year real rate on indexed bonds for the G7, based on the updating of Rachel and Smith (2015). It shows how the real rate started decreasing long before the crisis, but the crisis lowered it further. As of this writing, it is still in negative territory. ${ }^{7}$ In reference to Hansen (1939), one of the authors has referred to this evolution as "secular stagnation".

What factors are behind this steady decrease are not well identified. Explanations fall into two groups: The first is that the rate of return to capital has decreased, leading to a decrease in all rates, risky or safe. The second is that the safety premium has increased, leading to a lower safe rate for a

\footnotetext{
${ }^{7}$ Since the crisis, long rates reflect in part the effects of $\mathrm{QE}$, and thus the decrease in the term premium. The short real rate shows however the same general evolution.
} 
given rate of return to capital.

Under the first explanation, one is looking for factors which have increased saving or decreased investment. Given the large degree of financial integration and the largely similar decrease in interest rates across countries, one must look for factors of potentially global importance. Research has identified a large number of potential culprits, from the "global savings glut" emphasized by Bernanke (2005), to the interaction between taxes and inflation, to the decrease in the relative price of capital goods, to the impact of lower growth on investment, to the effect of rising inequality and profit shares in raising saving, to demographics (see Rachel and Smith 2015).

Under the second explanation, one is looking for factors that have increased the demand for or reduced the supply of safe assets. Research has also identified a number of potential culprits, from the accumulation of reserves in the form of safe assets by emerging market central banks, to financial regulation and higher liquidity requirements for banks, to the decrease in the set of assets which were perceived to be safe before the crisis, to the perception of higher risk due to the financial crisis itself (see for example Caballero et al (2017)).

The abundance of potential factors, without a clear sense of their relative importance, makes it difficult to predict what will happen to safe rates. For example, the sharp decrease in the current account surplus of China, and even more so, of oil producing countries, may lead to higher rates. Or, as memories of the crisis fade, the equity premium may decrease, as it did after the Great Depression, leading to an increase in equilibrium safe rates. Market pricing indicates however that investors expect low real rates to prevail for a long time to come. As this paper is written, yields on 10-year indexed bonds are 0.4 percent in the United States, -1.1 percent in Germany, and -0.4 percent in Japan. 
Low interest rates, especially interest rates lower than growth rates, have essential implications, not only for monetary policy but also for fiscal and financial policies.

So far, the focus has been primarily on the implications for monetary policy, and the effective lower bound. While central banks have explored and used other tools, there is little question that the binding lower bound on short term nominal interest rates (zero, or slightly negative) limited the scope of monetary policy to sustain demand during the recovery.

Indeed, this has raised an old but fundamental issue of whether market economies naturally return to potential (as we saw earlier, a potential which might itself be moving, but this is a different issue). One of the first formal discussions was given by Patinkin (1948): in response to low output, the price level would decrease, leading to an increase in the real value of money, and an increase in demand. The standard story, as captured in the aggregate demand/aggregate supply model of textbook fame, is the following: Lower output would lead to a lower price level, which would lead to a higher real money stock, which in turn would lead to a lower interest rate, which, finally, would increase aggregate demand and output. This never felt like a very convincing stabilizing mechanism, especially in a world where central banks increasingly ignored the money supply and focused instead on the interest rate. When central banks adopted inflation targeting and interest rate rules, stability was shown not to be automatic, but to depend on a sufficiently aggressive feedback rule from output and inflation to the policy rate. The effective lower bound, which prevents this feedback from operating, puts into question whether the economy will indeed return to potential after a bad shock. Even away from the lower bound, a positive probability that the constraint will bind raises the same fundamental issue. The observation that 10-year breakeven inflation as inferred from indexed bond 
yields is 1.8 percent in the United States, 1.2 percent in Germany, and 0.5 percent in Japan-all below 2 percent inflation targets suggests that investors are not convinced about the ability of central banks to return and maintain economies at potential in the future.

The limits of monetary policy imply, other things equal, a larger role for other policies, in particular fiscal policy. And low interest rates raise many questions about the design of fiscal policy in such a context. If the interest rate is below the growth rate, could this be a signal that the economy is dynamically inefficient, in which case larger public debt is actually not only feasible, but also desirable? If the economy is dynamically efficient, but the safe rate is below the growth rate, can the state still issue debt without ever paying it back, and if it can, should it do so?

Finally, low interest rates also have implications for financial regulation and macro prudential policy, although these are less obvious. The main issue is the relation between low interest rates and risk taking. It has been argued that a combination of human nature, leading to reach for yield, and of agency issues, lead to more risk taking when interest rates are low. Also, by inflating asset values and reducing debt service costs, low rates may also lead to high leverage. Some channels suggest the relevance of low real rates, others the relevance of low nominal rates, such as the "break the buck" constraint perceived to be binding by money market funds. In either case, there is again an important role for financial regulation and macro prudential policy to play.

Having described the landscape, we turn to the implications for monetary, fiscal, and financial policies. 


\section{Monetary policy}

The crisis forced central banks to drastically change the way they conduct monetary policy. Most of the changes and the new instruments were introduced in the heat of the crisis. The question is, looking forward, how many of these instruments should remain, how monetary policy should be reconstructed. We focus on three issues, how to deal with the effective lower bound on interest rates, whether and how monetary policy should address financial stability concerns, and whether central banks should return to smaller balance sheets. ${ }^{8}$

The United States has experienced six recession episodes in the last fifty years. The reductions in policy interest rates have averaged 5 percentage points, ranging from 2.1 to 10.5 percentage points, as policymakers responded to these downturns. Given that the Fed now believes the long run normal Fed funds rate is only 2.75 percent and that markets do not expect rates to rise to this level for a decade or more, it is clear that there will be less scope for interest rate reduction as a response to economic downturn in the relevant future than in the past. This raises the risk that future downturns will be more serious, and that if this comes to be anticipated, investment will be reduced even in advance of downturns.

What can be done to mitigate this risk? As we have learned, and Yellen (2017) has recently emphasized, even when interest rates are at the lower bound, central banks have a range of tools at their disposal. These include the much discussed various forms of quantitative easing, forward guidance, and more ambitious strategies of committing to higher inflation when full employment is restored. We are skeptical that these will necessarily be suf-

\footnotetext{
${ }^{8}$ In this and the following sections, we also refer the reader to the specific presentations at the conference on monetary, fiscal, and financial policies. The paper on monetary policy was written by Ben Bernanke (2017).
} 
ficient. Were a recession to start in the United States, Europe or Japan, we would expect that long rates would fall to very low levels without any help from forward guidance or QE. This would leave little room for QE policies to decrease them further.

A natural solution, as argued by Rogoff (2017) would be to eliminate cash so as to eliminate the effective lower bound altogether. If people only had access to electronic demand deposits, those deposits could pay negative nominal rates without the risk of people moving into cash. It is indeed conceptually the most appealing solution. Like the other solutions below, it has potential shortcomings: To the extent that banks are reluctant to pass on negative rates to depositors, negative rates may reduce bank profits, and reduce lending. For large enough negative rates, the effect of reduced lending may dominate and lead to lower rather than higher demand (Brunnermeier and Koby 2017). ${ }^{9}$ And, while many economies are increasingly moving from cash to electronic money, it will take some time before cash is no longer an empirically relevant alternative. To the extent that there remains an effective lower bound and nominal rates cannot go too negative, other solutions must be found.

An alternative solution is to generate expectations of higher inflation when they are needed, namely when policy rates have hit the effective lower bound. Price level targeting, if credible, does achieve that. If the economy is in a recession, and inflation is low, the commitment to return to the price level path implies a commitment by the central bank to generate higher inflation later. Price level targeting however has a major shortcoming. It is symmetrical: If the economy is operating at potential, but inflation has been too high in the recent past, the central bank must be willing to return to the price level path, and thus must be willing to tighten monetary policy and risk a

\footnotetext{
${ }^{9}$ Brunnermeier and Koby refer to the rate at which the effect on demand changes sign as the "reversal rate".
} 
recession for no good reason beyond the previous commitment. This may be politically difficult, and by implication, not fully credible. Other solutions have been offered, for example the proposal by Bernanke in his contribution to this conference (Bernanke 2017) to commit to undo the shortfall of inflation during the time monetary policy is constrained by the effective lower bound, through higher inflation later. Yet, another alternative, suggested in Summers (2018) would be a shift to a nominal GDP target calibrated to assure nominal interest rates in normal times in the 4 percent range.

All these proposals rely on the credibility of commitments to achieve higher inflation in the future, and the ability of the central bank to move inflation expectations when and as needed. Japan's difficulty over the last four years in moving inflation expectations and achieving its inflation target, despite the strong commitment of both the fiscal authority and the central bank, reinforces our sense of the difficulty of moving expectations in this way. If such commitments are de facto incredible, then this leads one to consider permanent increases in target inflation, say from 2 percent to 4 percent (Blanchard et al 2010).

Whichever approach is chosen, we believe that the question of creating the capacity to respond to downturns is a critical one facing monetary policy today.

Turning to the role of monetary policy vis a vis financial stability, it is clear that financial regulation and macro prudential policies should be the first lines of defense. One cannot expect however that they will be fully successful. The question is then whether monetary policy, i.e. the use of the policy rate, should be the second line of defense. This discussion is known as "leaning against cleaning" (i.e. increasing the interest rate in the face of a credit boom or an asset bubble, versus taking measures in response to the later decrease). We are skeptical that monetary policy, in the form of move- 
ments in the policy rate, can play a very useful role:

First, and this is common to monetary policy and time-varying regulatory policies, it is in the nature of asset bubbles or unhealthy credit booms to be difficult to assess in real time. Alan Greenspan's famous "irrational exuberance" observation was made in December of 1996 when the Dow was at 6300. Given subsequent history, it is pretty clear that the stock market was not at that moment overvalued. More generally Goetzmann (2015) has shown that even when markets double over short intervals, they are more likely to double again than to fall in half, pointing up the difficulty of pricking bubbles without responding to upwards movements in asset prices that in fact reflect fundamentals. In the same way, unhealthy credit booms are often unhealthy only in retrospect.

Second, lags in the effects of monetary policy make it even harder to act in a way that is stabilizing. Monetary policy acts with a significant lag. A tightening of policy just before a bubble bursts is likely to exacerbate the subsequent contraction. The ability to use monetary policy to promote financial stability therefore depends not just on an ability to identify bubbles but to be sufficiently confident to act in response to them well before they would burst of their own accord.

Third, the interest rate is a very poor instrument to decrease risk. Higher interest rates may slow down credit growth, and lead to less risk taking. At the same time however, higher rates worsen the position of existing debtors, both directly and through their adverse effect on activity, increasing their risk of bankruptcy. They also weaken the position of financial intermediaries that have borrowed short and lent long.

For all these reasons, we believe, along the lines of Svensson (2017) and against the arguments of Borio and Lowe (2002) and Kashyap, Gourio, and Sim (2016), that using interest rates to fight asset bubbles or credit booms, has a good chance of being ineffective or counterproductive. Our judgment 
is financial regulation and macro prudential policies despite their flaws are likely to be more effective in promoting financial stability than varying interest rates.

If a crisis materializes however, we have little doubt that central banks should generously provide liquidity against good collateral, and in doing so limit the cost of cleaning. For reasons we develop later when discussing financial policies, we are skeptical of the moral hazard argument in this context. Liquidity provision is not the same as a bail out, is unlikely to have strong incentive effects, and liquidity provision can make the difference between a recession and a depression.

Turning finally to balance sheets: Between 2007 and 2016, the liabilities of the Bank of Japan increased from $21 \%$ to $89 \%$ of GDP, those of the Fed from $6 \%$ to $24 \%$, those of the ECB from $16 \%$ to $34 \%$. The increase in liabilities has mostly taken the form of interest paying money, i.e. reserves held by banks at the central bank. Assets are a mixture of government bonds and private securities, with the composition varying across central banks.

Looking forward, as central banks increase interest rates, should they keep such large balance sheets, or should they go back closer to the precrisis balance sheets?

It is important to recognize at the outset that in the institutional environment now prevailing in all major economies where central banks pay interest on bank reserves, "money" is now the equivalent of floating rate government debt. The monetary transmission mechanism stressed by both Friedman and Tobin, that relied on money paying zero interest rate, and so changes in the quantity of money changed all other interest rates and prices, is no longer a feature of modern economies. Rather what we call monetary policy is really interest rate policy as central banks set policy interest rates directly, and changes in "money" represent changes in the maturity and per- 
haps the credit structure of the debt the public has to absorb. In this world, the size of central bank balance sheets is not per se a measure of inflationary pressure, even in the long run. ${ }^{10}$

As Greenwood et al (2014) stress, any judgement about central bank balance sheets must reflect two quite different sets of considerations. It depends on a judgement about what is the optimal maturity structure of the debt that the consolidated government and central banks make available to the public. And given this judgement, it then depends on the optimal division of labor between the Treasury and the Central Bank.

Perhaps the best argument in favor of large balance sheets focuses on the liability side of the balance sheet and has been made by Greenwood et al (2016): They stress that some investors have a preference for very short maturity, very liquid, assets, and that the government is in a unique position to offer such assets. And the larger public provision of very liquid assets reduces the risk that the private sector manufactures its own through securitization, tranching and other means, an activity which proved dangerous and costly during the crisis. These assets could also be provided by the Treasury, for example in the form of long maturity floating rate debt, or, as is now the case, by the central bank in the form of interest paying reserves. One may argue that the central bank is in a better position to assess fluctuations in demand for these very liquid assets, allowing the Treasury to focus on more traditional debt management. If the central bank does it however, it should do so in such a way as to allow access not just by banks, but by those institutions which have the most need for such liquid assets.

A different line of argument holds that risk premia associated with longer maturity bonds, and with private sector instruments including equities, are excessive for reasons relating to either capital market constraints or behav-

\footnotetext{
${ }^{10}$ To be more explicit, when money pays interest, monetary aggregates become irrelevant to the determination of the price level, and so do velocity measures.
} 
ioral factors affecting investors. In this case the public sector can reduce its financing costs by borrowing short term and holding longer term assets. In the language of traders it can engage advantageously engage in carry trades and even collect the equity risk premium. At a minimum it can avoid being on the other side of the carry trade. Even if there are no such distortions, decreasing term premia loosen the zero lower bound: other things equal, if and when the short nominal rate reaches zero, longer maturity rates will be lower, thus helping aggregate demand.

Whatever the case is for shortening the maturity structure of the government debt that the public must absorb, we see however little argument for the current approach in the United States and most other countries where both the Treasury and the central bank act largely independently to affect the maturity structure of the debt and, as in the United States during the QE period, can even do it at cross purposes. We believe that, for the most part, debt management decisions should be taken by the Treasury, or by actions coordinated between the central bank and the Treasury. This leaves little role for large central bank balance sheets at times when the zero lower bound is not binding. Overall, we are not able to identify substantial economic benefits from large central bank balance sheets. ${ }^{11}$

In short, we are skeptical that monetary policy proper can be used to decrease the risk of a financial crisis. We also do not believe that the central bank needs to keep a large balance sheet in normal times. The central bank can increase its balance sheet quickly if and when needed. We see a central issue for monetary policy as fighting the next recession whatever its source.

\footnotetext{
${ }^{11}$ This raises another set of issues, about the optimal transition from the current balance sheets to smaller ones, and the joint use of the interest rate and balance sheet adjustment along the way. In general, given the larger uncertainty associated with the effects of balance sheet changes relative to policy rate changes, so long as output is not at potential, and inflation below the target, the interest rate should remain the primary instrument of adjustment. We do not discuss the issue further here.
} 
Efficacy in fighting recessions depends on how much room central banks have to maneuver.

\section{Fiscal policy}

Out of necessity, fiscal policy was rediscovered as a stabilization tool during the crisis, although, in the face of deficits, large increases in debt, and worries about debt sustainability, fiscal expansion quickly turned to fiscal austerity and debt stabilization. Today, fiscal policy faces a highly unusual environment: On the one hand, and largely because of the financial crisis, debt levels relative to GDP are high by historical standards. On the other hand, interest rates on government debt are low, and, in many countries, they are expected to remain lower than growth rates for some time to come. As a consequence, levels of government debt service relative to GDP are low by historical standards.

These evolutions raise two main issues: ${ }^{12}$

The first is how fiscal policy can be used as a stabilization tool. Given how short-handed governments were in reacting to the fall in demand in 2008-9, one might have expected both academic work and policy progress on the scope for discretionary policy, for example on whether it is feasible to have a set of truly "shovel ready" projects for public investment, or on improving or designing new automatic stabilizers. There has been surprisingly little academic work (for an exception, see MacKay and Reis 2016), and no policy progress that we know on this front. Work on the use of fiscal policy as a stabilization tool must actually go beyond just stabilizers: Another lesson from the crisis and of the renewed interest in fiscal policy, is the complexity of "multipliers", i.e. the effects of fiscal policy on demand and output, of their

\footnotetext{
${ }^{12}$ For a wider discussion of fiscal policy, we refer the reader to the presentation by Auerbach (2017) at the conference.
} 
dependence on the specific type of fiscal adjustment and the economic environment. Despite a large amount of research since the crisis, we still have a poor understanding, for example, of the effects of spending cuts versus tax increases, and on the supply side effects of alternative fiscal policies.

The second is how fiscal policy should be conducted in an environment of high initial debt but low rates on government bonds, indeed lower than the growth rates. To answer this question, it is essential to distinguish between the marginal product of capital and the safe rate, the rate on short maturity government bonds. Because the marginal product of capital (or claims to it, such as equity) is risky, investors will only hold it if it pays a higher expected rate of return than the safe rate. Distortions and liquidity considerations may further affect the spread. Thus, a safe rate lower than the growth rate may well be consistent with a marginal product of capital above the growth rate. ${ }^{13}$

An extreme version of the secular stagnation hypothesis is that, not only the safe rate, but also the risk adjusted marginal product of capital have become lower than the growth rate, reflecting an excess accumulation of capital in the world, a configuration referred to in the literature as "dynamic inefficiency". If this were indeed the case, then higher debt, to the extent that it crowded out private capital and thus increased the marginal product of capital, would actually be not only feasible but also desirable. The arguments would extend beyond debt. Pay-as-you go social security systems would dominate fully funded systems, reducing capital accumulation, but delivering higher welfare.

The evidence suggests however that, in most countries, the marginal product of capital remains substantially above the growth rate. More formally,

\footnotetext{
${ }^{13}$ Here and below, we are playing fast and loose here, in dealing with uncertainty. The safe rate, the marginal product, and the growth rate, all move over time. A more precise statement would be that the average safe rate lower than the average growth rate may well be consistent with an average marginal product above the average growth rate.
} 
the sufficient condition for dynamic efficiency derived by Abel et al (1989), namely that the total returns to capital exceed levels of investment, appears largely satisfied. ${ }^{14}$ On balance, we think it most likely that we are in a situation in which the safe rate is less than the growth rate but the risk adjusted marginal return to investment likely exceeds the growth rate. However, a definitive judgment must await theoretical and empirical research.

This in turn raises two issues. Given that they can finance themselves at the safe rate, can governments issue debt and never pay it back? And if they can, should they?

If we were sure that the safe rate were to remain smaller than the growth rate forever, then indeed the government could issue debt, distribute the proceeds in the form of reduced taxes or increased spending, and never raise taxes nor repay the debt: The debt-to-GDP ratio would not explode, but instead converge to a finite value, no matter how large the deficit.

Given our limited understanding of the relative role of the factors that lie behind the low safe rate, we cannot be sure however that the inequality will not reverse at some point in the future. ${ }^{15}$ If so, if and when it happens, the government will need to raise taxes or decrease spending in order to stabilize debt. From the government point of view, it may still be an attractive debt gamble (to use the expression coined by Ball et al 1998): The lower the probability that the inequality is to reverse, the smaller the expected tax burden associated with any initial debt issuance. Furthermore, the concern that the

\footnotetext{
${ }^{14}$ Two caveats: Returns to capital may reflect in part markups over marginal costs, and thus include a rent component. Recent evidence by De Loecker and Eeeckout (2017) suggests that markups have substantially increased over the last 40 years, implying lower marginal products of capital for given rates of return to capital. Another intriguing piece of evidence, by Geerolf (2013), is that the Abel et al condition (which is a sufficient, not a necessary condition, for dynamic efficiency) is not satisfied in some countries. Nevertheless, despite these two caveats, we see the bulk of the evidence as supportive of dynamic efficiency.

${ }^{15}$ In the presence of distortions or incomplete markets, the inequality may hold forever. See for example Blanchard and Weil (2001)
} 
safe rate may eventually exceed the growth rate is substantially mitigated if governments can actually lock this low rate for a long time through the issuance of long term indexed debt. The real interest rate on 30-year indexed debt is 0.9 percent in the United States today and lower still in Germany and Japan, which seems very low relative to even pessimistic views about long term growth.

If governments can issue debt at little or no cost in terms of future taxes, does this mean that they should do it? The answer is, not necessarily, except for the usual stabilization or public investment reasons (to which we return below). The main reason is simply that the increase in debt while permitting lower taxes and higher consumption in the short run will ultimately lead to lower capital accumulation, and, if the economy is dynamically efficient and output is at potential, lower consumption. ${ }^{16}$ Working in the opposite direction however, some of the explanations for the low safe rates suggest that higher debt may reduce some distortions and thus increase welfare. For example, to the extent that higher debt leads to a higher safe rate, this decreases the risk that the economy hits the effective lower bound, and thus increases the room of maneuver for monetary policy. Or, to take another example, if the low safe rate reflects in part a "shortage of safe assets", as argued for example by Caballero et al (2017), increasing the supply of public debt may reduce this shortage, increase the safe rate, and increase welfare. Other measures, such as changes in financial regulation or reductions in the maturity of the debt without changing the total amount (as we discussed in the section of monetary policy), may however achieve the same outcome.

How do these theoretical considerations translate into practical policy advice?

\footnotetext{
${ }^{16}$ While this implies that there is no feasible Pareto improvement, it still makes the tradeoff between current and future consumption more attractive. Thus, for a government that maximizes a given social welfare function, it may lead to larger debt issuance.
} 
Take stabilization first. To the extent that the low safe rates imply sharper limits on monetary policy, this implies an increased need for the use of fiscal policy for stabilization purposes. At the same time, the same low safe rates imply more space to use fiscal policy for such purposes. Both go in the same direction, an increased use of fiscal policy relative to monetary policy.

Turning to debt policy, the objective must still be to decrease the ratio of public debt to GDP over time, but, just as low safe rates imply the need to reexamine the inflation target, they also imply the need to reexamine the speed of debt adjustment. For example, too fast an adjustment may require lower safe rates to sustain demand, reducing the room for monetary policy to counteract the effect of fiscal consolidation on demand.

A final issue concerns public investment. From a fiscal point of view, public investment can be financed at the low safe rate, which makes it attractive. But the low safe rate is not the relevant opportunity cost: If the economy is operating at potential, and higher demand does not affect potential output, increased public spending has to come at the expense of private spending. To the extent that private spending is crowded out, the relevant comparison is thus not between the rate of return on public investment and the rate on government bonds, but rather between the rate of return on public investment versus the opportunity cost of private consumption and investment being crowded out. It may still be, and we believe this to be the case, that, in many countries, the rate of return on public investment is sufficiently high that public investment should be increased, and financed by debt; but this is the case to be made, not just a comparison between the marginal product of public investment and the safe rate. Hysteresis, which we discussed earlier, is also directly relevant here. Even if the interest rate exceeds the growth rate, and to the extent that higher actual output leads to higher potential output, it may be that public spending pays for itself, leading to a decrease in the debt to GDP ratio even in the long run (DeLong 
Summers (2012)). The case becomes even stronger when the interest rate is below the growth rate.

\section{Financial policies}

Based on recent experience, a large fraction of whatever consequential instability takes place in advanced economies over the next decades is likely to be associated with financial instability. Note that, in addition to the experience of the Great Recession, the other recent economic downturns in the United States had some roots in financial factors-be it the credit problems associated with real estate and consequent credit crunch in the late 1980s, and the stock market bubble and its collapse in 2000.

This raises the issue of both crisis prevention and crisis resolution. ${ }^{17}$

Take crisis resolution first. Some believe that one lesson of the crisis is that policymakers need stronger tools for responding to financial strains, so that for example next time there would be clear legal authority to bailout an institution like Lehman in 2008. Others believe instead that the moral hazard associated with the excessive availability of bailout funds was an important contributor to the excessive risk taking that led to the crisis.

We are skeptical of the moral hazard fundamentalism that has taken hold in many quarters and concerned that both legal changes and the painful political lessons of the past crisis may make the provision of emergency liquidity more difficult the next time a crisis comes along. Serious concerns have been expressed by Geithner (2017) and others that legal restrictions contained in the Dodd-Frank legislation on the provision of support to individual institutions could make an appropriate response to the next crisis more difficult. To a substantial extent, crises have their roots not in con-

\footnotetext{
${ }^{17}$ For a wider discussion of financial policies, we refer the reader to the presentation by Aikman et al (2017) at the conference.
} 
scious risk taking by financial institutions, but in "black swan" events that they do not anticipate-something that cannot be changed by altering incentives. Moreover the provision of liquidity that contains runs arguably does not represent a moral hazard cost because it need not be socially costly. Indeed, as we mentioned earlier, the United States government turned a profit on the TARP program of support for financial institutions. Because major crises only occur every half century or so, we are skeptical that actions in one crisis are important as precedents for the next.

Crisis prevention has been a major preoccupation since the onset of financial crisis in 2008, leading to the passage of Dodd-Frank in the United States, and the myriad of internationally coordinated activities under the auspices of the FSB. Capital ratios have been substantially increased. Systemic banks are subject to tighter constraints. Stress tests have steadily improved. Liquidity ratios have been introduced to limit the risk and the consequences of runs.

Yet, by necessity, regulatory practice has run somewhat ahead of theory. There is a multitude of unresolved questions ranging from how central the adequacy of capital is relative to other issues, to the desirability of using multiple capital ratio requirements, to how regulation should vary with cyclical and financial conditions, to whether and how best to regulate the "shadow financial system", to how to avoid liquidity breakdowns and major disruptions in asset markets. ${ }^{18}$ Here we focus on just two-the efficacy of capital regulation and stress tests, and the desirability of time varying regulatory policies to promote stability.

It is tempting to suppose that, with sufficiently high capital requirements, the stability of major institutions and hence of the financial system can be assured. High levels of capital can be assured in a static sense through direct

\footnotetext{
${ }^{18}$ For an assessment of bank regulation, see Goldstein (2017).
} 
capital regulation and in a dynamic sense through stress tests that assure that capital levels will be adequate even in an adverse scenario (leaving aside issues of liquidity, which indeed require an additional instrument).

Bulow and Klemperer (2013) and Sarin and Summers (2016) discuss a number of issues raised by current approaches to capital regulation. Most of the institutions that failed in 2008 and 2009 were reported by their regulators to have high capital ratios up to the moment when they failed. As a particularly egregious example, Bear Stearns was reported by its regulator to have a Tier 1 Capital Ratio of 11.6 percent the week before it failed. But it is not an isolated example: Wachovia, WaMu and Lehman all were judged to have high capital ratios on the eve of their failures. Haldane and Madouros(2012), looking at the universe of large global banks, report that there was no correlation between prior capital ratios and chance of survival through the crisis. Bulow and Klemperer note that banks that are resolved by the FDIC typically have liabilities 15 percent or more in excess of assets suggesting large flaws in regulatory capital as a measure of economic capital.

While the official line is that the banking sector is far better capitalized than it was prior to the crisis, Sarin and Summers note that ratios of the market value of equity to bank assets, measures of equity volatility, and returns on preferred stock all suggest otherwise. Stress tests suggest an extraordinary robustness of the banking system at least in the United States today, but we suspect that claims that the system would weather a storm far worse than 2008 without any large institution needing to raise capital say more about stress test methodologies than they do about banking system robustness.

This has direct policy relevance. A major policy error made in association with the 2008 crisis was the failure of regulatory authorities in the United States to force the raising of capital or at least the reduction of dividend payments and stock repurchases in the Spring and Summer of 2008 even as markets were signaling serious concerns about the health of the financial 
system. It can be debated whether this reflected failure of the authorities to perceive the extent of the risk, or their lack of legal authority. How to avoid similar delays in the future, and how to design approaches using market information as an input to regulatory policy seem to us a priority.

While we believe that regulatory policies that are more responsive to changes in firms' economic capital are desirable, we are more skeptical of time-varying capital requirements or leverage limits. In part this is for the reasons discussed earlier with respect to the use of monetary policies to promote financial stability. It is very difficult to identify bubbles or excessive credit booms ex ante and even more difficult to confidently identify them enough ahead of their bursting to make countercyclical policy worthwhile. Contrast the difficulty of the task of noticing and acting on capital depletion of banks in 2008 at which the authorities failed despite clear market signals, with the task of gauging early incipient bubbles and acting on them. Political economy issues further complicate the task: Increasing required down payments on mortgages in the face of an increase in housing prices, which is likely to primarily affect young buyers, may be extremely unpopular, and, as a result, applied too little or too late. Indeed, there is a clear risk that time-varying macroprudential measures respond to recent experience and end up prorather than counter-cyclical.

These considerations suggest financial stability benefits of higher and constant capital ratios, rather than lower and cyclically sensitive ones. The cost of doing so may be small. Indeed one of the most interesting findings of the research since the crisis is that, leaving aside the risk that some activity shifts to the shadow banking sector (which thus needs to be regulated as well) higher capital ratios have limited effects on either the cost of funds for banks or on bank lending, leading to the conclusion that higher capital ratios than the current regulatory ratios may well be appropriate (Goldstein 
2017).

In short, while much more attention is now paid to financial regulation and macro prudential policies, the task is far from finished. The very complexity of the financial system, our limited understanding of its workings, the ability of the financial players to adjust and engage in regulatory arbitrage are formidable obstacles. We are likely to face more financial crises in the future.

\section{Conclusions}

As the crisis fades in the rear view mirror, we perceive a risk that macroeconomic policy returns to business as usual, that central banks return to the inflation targeting of the past, that there is little progress on the use of fiscal policy, and that there is a successful push back on the part of financial institutions against what they argue are excessive capital and liquidity requirements.

This would clearly be wrong. Ten years ago, few would have predicted the events which were to unfold, from runs on the largest world financial institutions, to interest rates at liquidity trap levels for close to a decade, to inflation still below target today, to output gaps being still large and negative in many advanced economies. We view the basic lessons from the Great Financial Crisis to be largely similar to those drawn by the Keynesian revolution in response to the Great Depression: Economies can be affected by strong shocks, and cannot be expected to automatically self stabilize. We have no doubt that, absent the strong monetary and fiscal policy responses we have observed, the financial crisis would have led to an outcome as bad or worse than the Great Depression. Thus, strong stabilization policies are simply of the essence. 
Should we think of the required changes as evolution or revolution? ${ }^{19}$

The case for evolution goes as follows. True, on the research front, our models of fluctuations have been more models of regular tides than models of potential tsunamis. But we can incorporate many of the non-linearities that the crisis has revealed (for example Gertler et al 2017). On the policy front, macroeconomic policy must rely on all three legs, monetary, fiscal, and financial. Monetary policy has to recreate a sufficient margin of maneuver to respond to adverse shocks in demand, something it can achieve in a number of ways. Fiscal policy has to play a larger stabilization role, through the development of better stabilizers, and debt consolidation can happen at a lower pace. Better financial regulation has already substantially decreased the risk and the consequences of financial crises, but needs to be further adjusted. If these steps are taken, we should be able to handle future shocks in a better way.

The case for revolution goes as follows. Suppose that secular stagnation turns out to require large negative interest rates or unsustainable asset price increases and credit expansions, to maintain demand and keep output at potential. To recover its margin of maneuver, monetary policy must then consider more dramatic measures, such as a much higher inflation target, or the purchase of private assets on a large scale. Large sustained fiscal deficits may be needed to sustain demand without excessive private sector leverage and risk taking. Given the limits of financial regulation, and the increased risk taking triggered by negative safe rates, more dramatic measures may have to be taken to redefine the scope and the size of the financial system.

The case for revolution may seem far fetched, but the experience of Japan over the last 20 years must serve as a warning. As is well known, the potential growth rate of Japan is low, around $1 \%$, reflecting limited produc-

\footnotetext{
${ }^{19}$ The authors have different views on this question. Blanchard is inclined to see the need for evolution, Summers more inclined to see the need for revolution.
} 
tivity growth and adverse demographics. Think however of what Japanese macroeconomic policy has had to resort to in order to sustain demand and maintain this $1 \%$ annual growth over the last 20 years: Interest rates, both short and long close to zero, large fiscal deficits leading to a very large increase in public debt, massive central bank purchases, and recourse to external demand in the form of a current account surplus. Put another way, in the face of very weak internal private demand, Japanese macroeconomic policy has had to rely on extreme macroeconomic policies, including recourse to foreign demand, an option which would not be available to other countries if the same weakness were to affect all of them. Were Japan to be a template of things to come for the rest of advanced economies, what would be needed would indeed be a macroeconomic policy revolution.

Could this realistically be the case? As we write, the cyclical outlook in the US and Europe looks good, with relatively strong growth. This growth is sustained, on the demand side, by strong growth in asset prices, especially corporate stock prices, an asset price growth which we should not expect to continue at the same rate in the future. History teaches that recessions are almost never forecast even a year in advance. If the United States or Europe were to go into recession in the next couple of years, in all likelihood their situation would look much like that of Japan with zero rates, large fiscal deficits, below target inflation and inadequate growth. We may be one cyclical downturn away from a need for revolution. Time will tell whether it comes. 


\section{References}

[1] Andrew Abel, N Gregory Mankiw, Lawrence H Summers, and Richard J Zeckhauser. Assessing dynamic efficiency: Theory and evidence. Review of Economic Studies, pages 1-20, 1989.

[2] Alan Auerbach. Fiscal policy. October 2017. Manuscript, presented at the "Rethinking macroeconomic policy" conference, Peterson Institute for International Economics.

[3] Laurence Ball, Douglas Elmendorf, and N. Gregory Mankiw. The deficit gamble. Journal of Money, Credit, and Banking, 30(4):699-720, November 1998.

[4] Ben Bernanke. On Milton Friedman's Ninetieth birthday. November 2002. Remarks at the Conference to Honor Milton Friedman, University of Chicago.

[5] Ben Bernanke. The global saving glut and the U.S. current account deficit. March 2005. speech at the Sandridge Lecture, Virginia Association of Economics, Richmond.

[6] Ben Bernanke. The Courage to Act: A Memoir of a Crisis and Its Aftermath. Norton, 2015.

[7] Ben Bernanke. Monetary policy in the new era. November 2017. Manuscript, presented at the "Rethinking macroeconomic policy" conference, Peterson Institute for International Economics.

[8] Olivier Blanchard. Should we reject the natural rate hypothesis? Journal of Economic Perspectives, forthcoming, 2018.

[9] Olivier Blanchard, Giovanni Dell'Ariccia, and Paolo Mauro. Rethinking macroeconomic policy. IMF Staff Position Note 10/03, 2010. 
[10] Olivier Blanchard and Lawrence Summers. Hysteresis and the European unemployment problem. NBER Macroeconomics Annual, pages 15-90, 1986.

[11] Olivier Blanchard and Philippe Weil. Dynamic inefficiency, the riskless rate, and debt Ponzi games under uncertainty. Advances in Macroeconomics, 1:1-23, 2001.

[12] Claudio Borio and Phillip Lowe. Asset prices, financial and monetary stability: Exploring the nexus. BIS Working Paper 114, 2002.

[13] Markus Brunnermeier and Yann Koby. The "reversal interest rate": An effective lower bound on monetary policy. Princeton Working Paper, May 2017.

[14] Jeremy Bulow and Paul Klemperer. Market-based bank capital regulation. 2013. Economics Papers, 2013-W12, Nuffield College.

[15] Ricardo Caballero, Emmanuel Farhi, and Pierre Olivier Gourichas. The safe assets shortage connundrum. Journal of Economic Perspectives, 31(3):29-46, Summer 2017.

[16] Jan De Loecker and Jan Eeckhout. The rise of market power and the macroeconomic implications. August 2017. working paper.

[17] J. Bradford DeLong and Lawrence H. Summers. Fiscal policy in a depressed economy. Brookings Papers on Economic Activity, 2012.

[18] Douglas Diamond and Philip Dybvig. Bank runs, deposit insurance, and liquidity. The Journal of Political Economy, pages 401-419, 1983.

[19] John Fernald, Robert Hall, James Stock, and Mark Watson. The disappointing recovery of output after 2009. Brookings Papers on Economic Activity, 2017. 
[20] Milton Friedman. The role of monetary policy. American Economic Review, pages 1-17, 19681968.

[21] Jason Furman. Should policymakers care whether inequality is helpful or harmful for growth? 2017. Manuscript, presented at the "Rethinking macroeconomic policy” conference, Peterson Institute for International Economics.

[22] Peter Ganong and Pascal Noel. The effect of debt on default and consumption: Evidence from housing policy in the Great Recession. January 2017. Manuscript, Harvard University.

[23] John Geanakoplos. Solving the present crisis and managing the leverage cycle. Economic Policy Review, 16:101, 2010.

[24] Francois Geerolf. Reassessing dynamic efficiency. 2013. Working paper, UCLA.

[25] Timothy Geithner. Stress Test: Reflections on Financial Crises. Crown, 2014.

[26] Mark Gertler, Nobuhiro Kiyotaki, and Andrea Prestipino. A macroeconomic model with financial panics. December 2017. NBER working paper 24126.

[27] William Goetzmann. Bubble investing: Learning from history. NBER working paper 21693, 2015.

[28] Morris Goldstein. Banking's final exam: Stress testing and bank-capital reform. Peterson Institute for International Economics, 2017.

[29] Gita Gopinath. Rethinking macroeconomic policy. International economy issues. November 2017. Manuscript, presented at the "Rethink- 
ing macroeconomic policy" conference, Peterson Institute for International Economics.

[30] Robin Greenwood, Samuel Hanson, Joshua Rudolph, and Lawrence Summers. Government debt management at the zero lower bound. Brookings Institution, 2014.

[31] Robin Greenwood, Samuel Hanson, and Jeremy Stein. The Federal Reserves Balance sheet as a financial-stability tool. FRB Kansas City Economic Policy Symposium, 2016.

[32] Andrew Haldane and Vasileios Madouros. The dog and the frisbee. Proceedings - Economic Policy Symposium - Jackson Hole, pages 109-159, 2012.

[33] Alvin Hansen. Economic progress and declining population growth. American Economic Review, 29-1:1-13, 1939.

[34] Glenn Hubbard. Financial markets and financial crises. NBER and University of Chicago Press, New York, 1991.

[35] Anil Kashyap, Francois Gourio, and Jae Sim. The tradeoffs in leaning against the wind. 2016. NBER working paper 23658.

[36] Richard C. Koo. The world in balance sheet recession:causes, cure, and politics. Real World Economics Review, 2011.

[37] Rachel Lukasz and Thomas Smith. Are low real interest rates here to stay? 2015. Bank of England Staff Working Paper 571.

[38] Alisdair McKay and Ricardo Reis. Optimal automatic stabilizers. 2016. CEPR discussion paper 11337. 
[39] Atif Mian and Amir Sufi. House of Debt. University of Chicago Press, 2014.

[40] Hyman Minsky. The financial instability hypothesis. The Jerome Levy Economics Institute Working Paper No 74, 1992.

[41] Don Patinkin. Relative prices, Say's law, and the demand for money. Econometrica, pages 135-154, 1948.

[42] Henry M Paulson. On the Brink: Inside the Race to Stop the Collapse of the Global Financial System. Business Plus, 2010.

[43] Edmund Phelps. Phillips curves, expectations of inflation and optimal unemployment over time. Economica, pages 254-281, 1968.

[44] Edmund Phelps. Inflation Policy and Unemployment Theory. Norton, New York, 1972.

[45] Ken Rogoff. The Curse of Cash: How Large-Denomination Bills Aid Crime and Tax Evasion and Constrain Monetary Policy. Princeton University Press, 2017.

[46] Paul Romer. The trouble with macroeconomics. 2016. Commons Memorial Lecture of the Omicron Delta Epsilon Society. Forthcoming in The American Economist.

[47] Natasha Sarin and Lawrence H. Summers. The bank capital volatility puzzle. Brookings Papers on Economic Activity, 2016.

[48] Lawrence H. Summers. Secular stagnation and macroeconomic policy. Forthcoming, 2018.

[49] Lars Svensson. Cost-benefit analysis of leaning against the wind. Journal of Monetary Economics, pages 193-213, 2017. 
[50] Janet Yellen. Opening remarks: The Federal Reserve monetary policy toolkit: Past present and future. Economic Policy Symposium - Jackson Hole, 2017. 